\title{
Effect of Cooperatif Learning Strategy And Interest Learning To Learning Outcomes History Student Class X SMK 1 Affairs Peureulak Lesson Year $2018 / 2019$
}

\author{
Helvi Maisyara \\ Postgraduate Program of State University of Medan \\ State University of Medan \\ Medan, Indonesia \\ helvimaisyara@gmail.com
}

\author{
Abdul Hasan Saragi, Derlina \\ Postgraduate of State Univeristy of Medan \\ State University of Medan \\ Medan, Indonesia
}

\begin{abstract}
Is the learning outcome history between students taught with Jigsaw learning strategies higher than the STAD learning strategies. (2) Are students 'history learning outcomes taught by Jigsaw learning strategies that have a high learning interest higher than students' history learning outcomes taught by STAD learning strategies? (3) Are there interactions between learning strategies and learning interest in student history learning outcomes? This research is quasi experimental research with post test only control group design. Population this research is the student of class X SMK 1 Peureulak. The sample selection was done by cluster random sampling. The sample is devide inti two class. The experimental class taught bye the Jigsaw strategy and STAD. The data is this study were analyzed by two-way ANAVA. The result og the research shows that: (1) learning outcomes History between students who are taught with Jigsaw learning strategies is higher than STAD learning strategies. (2) student history learning outcomes that are taught by Jigsaw learning strategies that have high learning interest are higher than students' history learning outcomes taught by STAD learning strategies, (3) there is an interaction between learning strategies and learning interest in student history learning outcomes.

Keywords: Cooperative Learning, Jigsaw, STAD, The Result Interest Learning
\end{abstract}

\section{INTRODUCTION}

The importance of education for humans especially in Indonesia has resulted in the education sector having to receive special attention from the government. The government plays an important role in improving the education system in Indonesia today which requires improvements to be able to later improve the standard of education in Indonesia so that it is not less competitive with education in other countries. In line with this, in the Republic of Indonesia Law No. 20 of 2003 concerning the National Education System (SPN) in Chapter 1, article 1 paragraph 2 is stated as follows: National Education is education based on Pancasila and the 1945 Constitution which is rooted in religious values, Indonesian National Culture and responsiveness to the demands of changing times. (Ministry of National Education, Law No.20 Th. 2003: article 3).

So far, learning in schools is still dominated by the view that knowledge is a fact to be memorized. Learning so far has only focused on providing students with knowledge skills that are more theoretical. Learning must always be related to the actual problems that occur in the environment. student's life. For that, a learning strategy approach is needed that puts forward student activities as the subject of Rusman's learning (2012: 187).

History Education is an important vehicle in the education of a nation. A reality that cannot be denied by many countries in the world puts historical education as an important element in their national education. This is because the belief that historical education material is able to develop the nature and character of the nation's young generation. When this young generation becomes the main and supporting role holder in carrying out the life of the nation, the character that has been formed in them becomes a strong foundation in carrying out this role.

The principles that need to be considered in the study of history are the learning of history based on the continuity of what happened in the past with the present life between historical events at the national level and the level of reason, and understanding of local level historical events based on the integrity of a historical event so that in the development of an understanding of the continuity between what happened in the past with current life, in the historical period of the students are directed to be able to find physical relics such as photographs of artifacts, drawings or sketches of historical areas or abstract relics (traditions, thoughts, views of life, values, habits ) in society inherited from historical events in the Restu period (2014: 7)

Based on my observation to the Principal of the Peureulak Vocational School about the phenomenon of historical learning taking place in schools. The fact that there is now, historical teaching strategies are far from expectations to enable children to see their relevance to present and future lives. Starting from elementary to high school level, historical education tends to only use historical facts as the main material. It is not strange that education here feels dry, unattractive, and does not provide opportunities for students to learn to explore the meaning of a historical event. Finally, it needs to be reaffirmed that historical education is actually a very important tool in the 
cultivation of nationalist values and national struggles. If history is considered a boring subject, then it is the duty of all parties, not just history teachers, but also historians and policy makers in curriculum development, to find solutions to solutions to this problem. Interest can serve as a driver of business in achievement and great influence on learning activities. The learning process will run smoothly when accompanied by interest. Therefore, the teacher needs to arouse students' interest so that the lessons given are easy for students to understand. Teachers must be able to generate motivation and foster confidence and can ensure that history lessons are not boring lessons. Besides giving motivation and fostering confidence in students, at the same time the teacher also constantly strives to facilitate the understanding of mastery of the material to students.

Therefore, the right effort is needed to foster a sense of pleasure towards historical subjects, one of which is the use of learning strategies that can make students active. One learning strategy that is expected to be able to help students to develop the ability to cooperate and be able to foster critical thinking is cooperative learning. Cooperative learning is one of the learning strategies that is not only able to develop students' competencies but is also able to provide experience to students and is able to develop collaboration in groups primarily in finding and solving learning problems.

Based on the explanation of the problems described above, this is what researchers are interested in researching, how much influence the cooperative learning strategy compared to conventional strategies on learning outcomes history. The researcher intends to raise this problem in the form of a study entitled "The Effect of Cooperative Learning strategies (Jigsaw and STAD) and Learning Interests Against the History of Class X Student Learning Outcomes at Peureulak State Vocational School, East Aceh District."

\section{REVIEW OF THE LITERATURE}

\section{Learning History Results}

History is simply interpreted as an imitation of the origin and development of events that have occurred. According to Taufik Abdullah, history can be seen in several aspects, namely history can be used as advice, for example by quoting Sukarno's words "Do not occasionally overtake history" This means that history is a wisdom that can guide us in navigating life today and pioneering the future. History can also be interpreted as a "teacher" in the field of philosophy. Hegel (Restu. 2014: 2) states that "history is the highest process of thinking towards humanity". According to Pujo Sukirno (Restu. 2014: 2) Learning outcomes of historical subjects include academic skills of historical awareness and nationalism. Academic skills are related to the cognitive domain which refers to competency standards and basic competencies that are developed in learning derived from the applicable curriculum. Assessment of historical awareness (historical awareness) includes the ability to: 1) live the meaning and nature of history for the present and the future; 2) know yourself and their people; 3) civilizing history for the development of national culture; and 4) maintaining the nation's historical heritage. Whereas the aspect of nationalism concerns: 1) the feeling of pride of students as Indonesians; 2) a sense of love for the country and nation; 3) willing to sacrifice for the nation; 4) accept plurality; 5) proud of a diverse culture; 6) appreciate the services of the heroes; and 7) prioritizing group interests. History learning outcomes are results that have been obtained after students have gained knowledge during the teaching and learning process in the history of social studies subjects which are realized in the form of scores (numbers) and obtained after taking tests or quizzes through measurement (evaluation) learning history student.

\section{Jigsaw}

The Jigsaw Learning Strategy was first developed by Eliot Aronson at the University of Texas and his colleagues. The method is a cooperative learning strategy where each student becomes a member in a particular field. Then divides his knowledge with other members of the group so that everyone can finally learn the concepts. According to Aronson, students are divided into several groups, each group member is given one task to do or parts of the research material to be corrected and revisited. Isjoni (2009: 78).

Jhonson and Jhonson (Fathurrohman, 2015: 25) conducted a study of cooperative learning jigsaw learning strategies whose results showed that cooperative interaction had various positive influences on child development. These positive influences are: a) improve learning outcomes, b) improve memory, c) can be used to achieve high-level reasoning, d) encourage the growth of intrinsic motivation (individual awareness), e) improve heterogeneous human relations, f) improve positive children's attitudes toward school, g) increase positive attitudes towards teachers, h) increase children's selfesteem, i) improve positive social adjustment behavior) improve life skills in mutual cooperation. In accordance with the research conducted by Hanita (2015) he stated that the learning outcomes of biology students taught with jigsaw techniques were higher than the learning outcomes of students taught with IOC techniques.

\section{STAD (Student Team Achievement Division)}

STAD (StudentTam Achievement Division) cooperative learning was developed by Robert Slavin and his friends at John Hopkins University. Students in a particular class are broken down into groups of 4-5, each attempted to have heterogeneous members, consisting of men and women, from various ethnic groups, having high, medium and low abilities. Team members use activity sheets or other learning tools to complete the subject matter and then help each other to understand the discussion lesson material and the Kurniasih quiz (2016: 22).

\section{Interest Learning}

According to Gie (Khairani, 2013: 142) that interest means being busy, interested or fully visible with something activities because it is aware of the importance of the activity, a great interest in its influence on learning activities, if students are interested in a lesson then the student will study it seriously like study hard, feel happy to take lessons and can even solve difficulties in learning because of the attraction to the lesson, interest also gives rise to spontaneous attention that allows the creation of concentration for a long time, thus interest is the basis for concentration. Interest is very personal where others 
will not be able to grow it in students, cannot maintain and develop that interest, and may not be interested in something as a representative of each student.

According to Holland (Khairani 2013: 137) that experts who research a lot about interest gives an understanding that interest is an activity or tasks that evoke feelings of curiosity, care and give pleasure or enjoyment. Learning with interest will encourage students to learn better than learning without interest. However, interest without good business learning is also difficult to succeed. (Hamalik, 2010: 33). Interest can be an indicator of one's strength in certain areas where he will be motivated to learn and show high performance.

\section{METHODOLOGY}

The location of the study was carried out in East SMKA. The time of the study was conducted in the even semester in March academic year 201/2019. The population in this study were all students of class $\mathrm{X}$ in even semester consisting of 4 classes with a total of 144 students. And dirandomsampling into 2 classes each class consisting of 36 students. This study uses factorial design $2 \times 2$ as the first independent variable is the use of learning strategies that are distinguished on Jigsaw learning and STAD learning. Moderator variables are students' learning interests, with grouping of interest in learning. High learning interest and low learning interest.

TABLE 1 Factorial Design 2 × 2

\begin{tabular}{|l|l|l|}
\hline \multirow{2}{*}{ Interest to learn } & \multicolumn{2}{|l|}{ Learning strategies } \\
\cline { 2 - 3 } & Jigsaw $\left(A_{1}\right)$ & STAD $\left(A_{2}\right)$ \\
\hline Height $\left(B_{1}\right)$ & $A_{1}, B_{1}$ & $A_{2}, B_{1}$ \\
\hline Low $\left(B_{2}\right)$ & $A_{1}, B_{2}$ & $A_{2}, B_{2}$ \\
\hline
\end{tabular}

Information:

A: Learning Strategy

B: Learning Interest

A1: Jigsaw learning strategy

A2,: STAD Teaching Strategy

B1: Learning interest is high

B2: Low Learning Interest

A1, B1: Learning outcomes History of students taught using the jigsaw model in High Learning Interests ..

A1, B1: Learning outcomes Student history taught uses jigsaw strategies for low learning interest.

A2 B1: Learning outcomes of students who have high learning interest by using STAD learning strategies

A1B2: Learning outcomes of students who have an interest in learning

A2 B2: Low student learning outcomes using the STAD learning model

Data analysis techniques in this study use descriptive analysis and inferential analysis. Descriptive analysis techniques are intended to describe research data including mean, median, standard deviation, mode and median data. To test the validity of the hypothesis proposed in this study, the data analysis technique used was Analysis of Variance (Anava) Two Paths. The use of this technique with the intention that the final test results achieved by the research subject really because of the influence of the treatment given during the study . The significant level used in this study is $\propto=0.05 \%$.
Furthermore, if the test results show that there is an interaction, it is necessary to do further testing with the Scheffe test if the number of students (n) per cell is different or the Tuckey test if the number of students (n) per cell is the same. Agunto (2002: 34)

\section{RESEARCH RESULT}

The results of testing the first hypothesis Based on the results of research conducted for students' history learning outcomes that were taught by the teaching and learning strategy of jigsaw obtained an average score of 84.11 while students who learned the STAD learning strategy only received an average of 72.89 . The history learning outcomes of students who were taught with the teaching and learning strategy of jigsaw were higher than the average scores of students who were taught with the STAD learning strategy. This is also shown in the calculation of the Scheffe test. This indicates that the strategy of teaching and learning is better in improving students' understanding of history than in learning strategies. This shows that in order to teach history lesson material it is better to use a jigsaw learning strategy compared to the STAD learning strategy. And this is in accordance with the research conducted by Rahmilawati (2015), which states that the economic learning outcomes of students taught with group investigation learning strategies are higher than students who are taught with student team achievement division learning strategies.

Based on the results of research conducted for student history learning outcomes with high interest in learning with jigsaw strategy gained an average score of 79.31 while students who had high learning interest with STAD strategy only gained an average of 78.4, so based on testing the second hypothesis it was proved that the high and low interest in learning had different influences not significant to student history learning outcomes where Fcount> Ftable, so for the second research hypothesis $\mathrm{Ha}$ is accepted and HO is rejected. So from this study it is clear that high learning interest gives a better influence and can improve student history learning outcomes compared to students who have low learning interest.

The findings of this study are the interaction between learning strategies and learning interests in influencing student history learning outcomes. When viewed on average the results of learning history of students who are taught with the strategy of teaching and learning and high learning interest is higher than the average learning outcomes of history of students who are taught with the STAD learning strategy and high learning interest. 


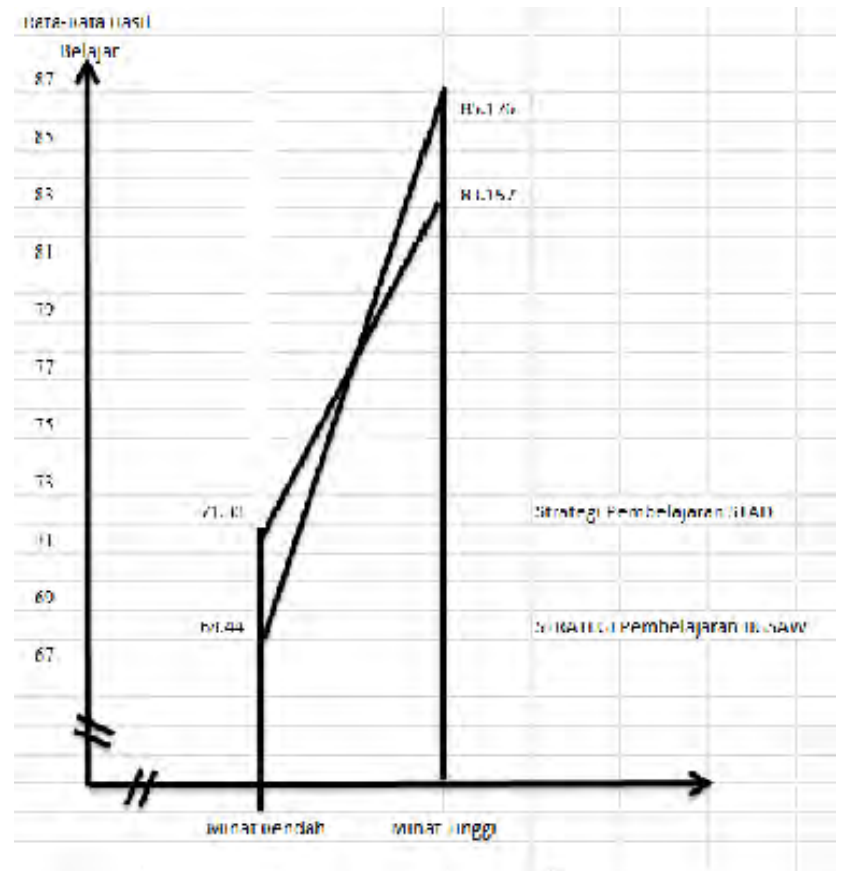

Fig 1. interaction between learning strategies and learning interests

\section{References}

[1] Arikunto, S. 2002, Research Institute, Edition Revisi V, Publisher Rineka Cipta

[2] RI Ministry of Religion's Directorate General of Islamic Education.2006. Indonesian Government Laws and Regulations on Education, 2006

[3] Fathurrohman, M., 2015. Models - Innovative Learning Models Alternative Fun Learning Designs. Mold I. Yogyakarta: AR - Ruzz Media.

[4] Hanita Khairani Lubis. 2015. Effect of Cooperative Learning Models and Intelligence on Biological Learning Outcomes. Education technology. Volume.8 No.1: ISSN: 1979-6692

[5] Hamalik Oemar. 2005. Teaching and Learning Process. Jakarta: Mount Agung

[6] Isjoni, 2009. Cooperative Learning - Improving the Intelligence of InterStudent Communication. Cetakan I, Yogyakarta: Learning Library.

[7] Restu Gunawan. 2014. History of Indonesia, Jakarta, Ministry of Education and Culture

[8] Rusman, 2012. Learning Models - Developing Teacher Professionalism. Second Edition, Jakarta: PT Raja Grafindo Persada

[9] Khairani, M., 2013. Learning Psychology. Yogyakarta: Aswaja Pressindo.

[10] Kurniasih, I., and Sani, B., (2016). Variety of Development of Learning Models for Improving Teacher Professionalism. Fourth Print. Jakarta

[11] Rahmilawati. 2015. Effect of Learning Strategies and Self-Confidence on Learning Outcomes of Biology. Educational Technology 7 Communication in Education. Volume: 2, No: 2 ISSN: 2355-4983 